https://doi.org/10.35339/msz.2019.85.04.11

УДК 616.89-008.44+616.89-008.442]:616.65-002-036.1

\title{
В.О. Кривицький
}

Харківська медична академія післядипломної освіти

\section{АНАЛІЗ ОСОБЛИВОСТЕЙ МІЖОСОБИСТІСНОЇ ВЗАЄМОДІЇ У ХВОРИХ НА ХРОНІЧНИЙ ПРОСТАТИТ I3 РІЗНИМ СТАНОМ ПОДРУЖНЬОЇ ЗАДОВОЛЕНОСТІ}

\begin{abstract}
Вивчено особливості міжособистісної взаємодії у хворих на хронічний простатит і їхніх дружин для визначення мішеней медико-психологічної допомоги даному контингенту. Обстежено 109 чоловіків, хворих на хронічний простатит, та їхніх дружин. За критерієм наявності / відсутності подружньої задоволеності обстежені пари були розподілені на дві групи. До першої групи ввійшли 73 (67,0 \%) подружжя з низьким або зниженим рівнем подружньої задоволеності, до другої - 36 (33,0 \%) подружніх пар, задоволених власними стосунками. Комплексне обстеження проведено стандартними клінічними, клініко-психологічним та психодіагностичним методами. Загальними негармонійними міжособистісними патернами, які впливають на розвиток подружньої незадоволеності, що призводить до вторинної травматизації подружжів через формування неадекватної психологічної відповіді на захворювання на хронічний простатит у чоловіка та пов'язані 3 цим порушення сексуальної реалізації, визначено такі деформації родинного спілкування, як зниження довірливості, взаєморозуміння, легкості та психотерапевтичності; превалювання ознак недовірливо-скептичного, прямолінійно-агресивного, залежного патерна міжособистісної поведінки або такого, що підкоряє; домінування агресії (32,9%) або уникання $(67,1 \%)$ як провідних стратегій психологічного захисту у спілкуванні. Отримані дані необхідно враховувати при розробці заходів медико-психологічної допомоги подружнім парам, у яких чоловік хворіє на хронічний простатит.

Ключові слова: хронічний простатит, подружня задоволеність, міжособистісне спілкування.
\end{abstract}

\section{Вступ}

За результатами сучасних досліджень, хронічний простатит (ХП) є результатом комплексної дії негативних психологічних, імунних, неврологічних та генетичних факторів і проявляється різноманітними урологічними й сексопатологічними симптомами та нервовопсихічними розладами [1]. Крім того, знайдено докази впливу психоціальних факторів на перебіг і прогредієнтність ХП $[2,3]$, серед яких стан мікросоціальних - родинних - характеристик розглядається як важливий чинник про- тективного або, навпаки, провокуючого впливу на психологічний $\mathrm{i}$ - опосередковано - соматичний стан хворого [4-8]. Однією з найважливіших складових родинної протекції $€$ ресурс міжособистісної взаємодії, стан якого може як сприяти гармонізації стану пацієнта, так і знизити захисні ресурси організму.

Метою даної роботи $\epsilon$ вивчення особливостей міжособистісної взаємодії у хворих на хронічний простатит та їхніх дружин для визначення мішеней медико-психологічної допомоги даному контингенту.

(C) В.О. Кривицький, 2019 


\section{Матеріал і методи}

Із дотриманням принципів біоетики й деонтології на базі декількох установ урологоандрологічного профілю м. Харкова протягом 2012-2018 років обстежено 109 чоловіків, хворих на ХП, та їхніх дружин. Критерієм включення в дослідження, окрім наявності захворювання на ХП у чоловіків, була відсутність в анамнезі психічних і поведінкових розладів у обох із пари. Вік обстежених був від 25 до 40 років. Обидва з подружжя зазвичай входили в одну вікову групу (з різницею до 5 років). У першому шлюбі тривалістю від 3 до 7 років перебували 60,6 \% подружжів, у другому шлюбі тривалістю в середньому від 2 до 5 років 39,4 \%. Клінічна картина ХП у всіх обстежених супроводжувалась порушенням сексуальної функції, що в 70 (64,2\%) осіб представлено варіаціями еректильної дисфункції, у 39 $(35,8 \%)$ - поєднаним ураженням еректильної й еякуляторної функцій.

За критерієм наявності / відсутності подружньої задоволеності, стан якої визначали за допомогою опитувальника подружньої задоволеності А. Лазаруса (1997) [9], обстежені пари були розподілені на дві групи. До основної групи (ОГ) увійшли 73 (67,0 \%) подружжя 3 низьким (менше 80 балів) або зниженим (80112 балів) рівнем подружньої задоволеності, до групи порівняння (ГП) - 36 (33,0 \%) подружніх пар, задоволених власними стосунками (115-160 балів).

Комплексне обстеження проведено стандартними клінічними, клініко-психологічним і психодіагностичним методами. Стан міжособистісної взаємодії оцінювали з використанням методики «Діагностика спілкування в сім'ї» Ю.Є. Альошиної, Л.Я. Гозмана, О.М. Дубовської, за допомогою якої діагностували такі складові спілкування, як довірливість, взаємопорозуміння в парі, схожість у поглядах, спільність символів, легкість і психотерапевтичність спілкування [10], методики діагностики міжособистісних стосунків Т. Лірі [10] та методики «Визначення механізмів психологічного захисту у спілкуванні» В.В. Бойка [10]. Статистичний метод був використаний для оцінювання розбіжностей між групами та залежностей між факторами.

\section{Результати та їх обговорення}

Міжособистісна комунікація - важлива характеристика успішності партнерської взаємодії. До ознак ефективної комунікації пари відносять: відкритість, високу активність спілкування, забезпечення обговорень значущих проблем; спільність цінностей; адекватність самосвідомості, несуперечність вербальних і невербальних повідомлень; безоцінність і емпатійне прийняття партнера, що особливо важливо при виникненні стресових, фруструючих та проблемних ситуацій у сімейному житті [10]. Викривлення комунікаційних процесів, насамперед збіднення або скорочення комунікації, дефіцит емоційного тепла, низька інформованість партнерів про реальні потреби, інтереси і проблеми один одного, брак співпраці й кооперації в парі, призводять до труднощів у відносинах іє причиною, або фактором прогредієнтності перебігу подружньої дезадаптації.

Результати дослідження особливостей комунікації подружжів наведено в табл. 1. Як свідчать дані табл. 1, високо оцінили свою

Таблиия 1. Середні показники шкал за опитувальником "Спілкування в сім'ї», бали

\begin{tabular}{|c|c|c|c|c|}
\hline \multirow{2}{*}{ Шкала } & \multicolumn{2}{|c|}{ ОГ $(n=73)$} & \multicolumn{2}{|c|}{ ГП (n=36) } \\
\hline & чоловіки & дружини & чоловіки & дружини \\
\hline Довірливість & & & & \\
\hline Я & $6,6^{\star \wedge}$ & $8,3^{\#}$ & 10,4 & 16,3 \\
\hline партнер & 6,4 & $6,3^{*}$ & 18,7 & 12,5 \\
\hline Порозуміння & & & & \\
\hline я & 7,4 & $8,8^{\#}$ & 15,2 & 18,0 \\
\hline партнер & 6,7 & $5,0^{*}$ & $19,1^{\wedge}$ & 13,8 \\
\hline Схожість поглядів & $6,4^{*^{\wedge}}$ & $10,0^{\#}$ & 12,5 & 16,3 \\
\hline Символи & $7,1^{\#}$ & $6,3^{*}$ & 10,8 & 17,5 \\
\hline Легкість спілкування & $5,9^{*}$ & $3,8^{\#}$ & 14,9 & 13,8 \\
\hline ПТ спілкування & $6,3^{*}$ & $5,0^{*}$ & 14,3 & 15,0 \\
\hline
\end{tabular}

Примітка. Розбіжності статистично значущі між показниками: * чоловіків (або дружин) ОГ і ГП на рівні $\mathbf{p}<0,05$; \# чоловіків (або дружин) ОГ і ГП на рівні $\mathrm{p}<0,01$; $^{\wedge}$ подружжя однієї групи на рівні $\mathrm{p}<0,01$. Тут і в табл. 2,3 . 
довірливість у спілкуванні пари ГП із компенсованою подружньою взаємодією (причому ресурс довірливості з боку дружин був більший, ніж із боку чоловіків). Оцінюючи довірливість спілкування своїх партнерів, обстежені ОГ поставили низькі бали. Довірливість спілкування дає уявлення про потреби пар у вільному і спонтанному вираженні власних почуттів, емоцій, не піддаючи себе жорсткому самоконтролю і самоцензурі. Парам необхідно інтимне, емоційно-позитивне, довірливе спілкування, яке вимагає від партнерів співчуття, порозуміння. Довірливі відносини дають емоційну і психічну підтримку, захищеність та комфорт. При низькій довірливості відносин пари відчувають взаємну відчуженість і суто негативні емоції. Врешті-решт негативні емоції викликають тривогу, напруженість та пригніченість. У випадках, коли вони регулярно й постійно існують, стан депресії, при якому пригнічений настрій, стає хронічним. Довірливість - це основа успішних відносин. Якщо розглядати конфлікти 3 погляду довіри, будьякий конфлікт врешті-решт означає, що люди не в змозі нормально домовитись 3 якогось приводу.

Показники за шкалою взаємопорозуміння в обстежених парах виявились конгруентними за шкалою довірливості спілкування: найбільш висока здатність до взаєморозуміння була притаманна дружинам ГП (це відмічали як самі жінки, так і їхні чоловіки), що забезпечувало достатній ії рівень і серед чоловіків. Пари ОГ відрізнялись низькими показниками довірливості у стосунках, причому з боку як чоловіків, так і їхніх дружин. Відомо, шо в партнерських стосунках взаєморозуміння - це здатність і бажання слухати, почути і зрозуміти один одного, пізнати один одного, прийняти точку зору дружини, але це не означає, що потрібно погоджуватися з цією точкою зору. Головна відмінна риса продуктивного спілкування - визнання цінності іншого, навіть якщо його позиція інша.

Важливою причиною неуспішних сімейних відносин є розбіжність поглядів і рольових очікувань пари, помилковість установок на шлюб, несхожість життєвих цінностей. Крайнім ступенем порушення адаптації $€$ існування взаємовиключних очікувань пари і несхожість у розумінні подружніх ролей. У обстежених пар ОГ показники за шкалою «подіб- ність подружжя в поглядах» мали низькі значення, причому в чоловіків вони значуще відрізнялись від показників як хворих ГП $(\mathrm{p}<0,05)$, так і навіть власних дружин ( $<0,01)$, у яких ці показники також були невисокими. Проаналізовано схожість поглядів пар ГП і доведено більше співпадіння поглядів. Дружини оцінювали схожість поглядів вище, ніж чоловіки (хоча ця різниця не була статистично значущою). Подібність подружжів у поглядах і успішність спілкування обстежених ГП опосередковано сприяли виробленню таких спільних рис, як оптимізм, емоційність, доброзичливість та співчутливість. Чоловіків, належних до такого типу взаємодії, відрізняли в більшості такі якості: уміння брати на себе відповідальність, бути опорою, упевненість у собі, турбота про рівність у спілкуванні в парі, уважність, тактовність. Жінки-партнерки мали такі риси, як здатність до емоційної підтримки, спокійне ставлення до порад інших, здатність отримувати задоволення від допомоги іншим, відсутність суперництва $з$ чоловіком, що приводило їх до успішної взаємодії. Крім того, показником сумісності в парах були схожість життєвих цінностей, цілей та способів досягнення їх. У подружжів ОГ, на відміну від ГП, розбіжність в оцінці основних загальновизнаних цінностей зазначалась відразу за кількома параметрами в різних комбінаціях. До них належали: здоров'я, сім'я, цікава робота, матеріальна забезпеченість, суспільне визнання, відчуття своєї потрібності близьким, самостійність, упевненість у майбутньому, сексуальна гармонія та цікаве дозвілля.

Парні стосунки припускають загальну історію, традиції, символи - це спільні переживання і спогади подружжів; особлива мова, натяки, ласкаві прізвиська і т. п. Будучи невідомими й незрозумілими для інших людей, вони добре зрозумілі подружжям, народжують у них приємне і хвилююче відчуття особливого «таємного» союзу, розуміння один одного 3 напівслова. Формування сімейної мови - певних, узгоджених та легко пізнаваних поглядів, міміки, жестів, поз, сімейних символів, традицій, норм - $\epsilon$ важливою характеристикою подружнього спілкування. Сімейні реліквіїпредмети, пов'язані з певними «знаковими» подіями сім'ї, - також виконують важливу функцію стабілізації сімейного спілкування, взаємодії та формування парної самосвідомості, задає нормативність життя сім'ї. Отже, 
показники значень за шкалою подібності та розуміння сімейних символів виявились близькими до середнього рівня в обстежених ГП, що було значуще вище $(\mathrm{p}<0,05)$, ніж у подружжів ОГ.

Шкала «легкість спілкування» вказує на те, наскільки подружжя можуть налагодити між собою контакт, почати й закінчити розмову, наскільки вільно почувають себе, спілкуючись один з одним. Задоволеність сімейними відносинами значною мірою залежить від того, якою мірою кожен із подружжя може задовольнити власну потребу у спілкуванні з партнером і відчуває задоволення від такого спілкування. Правила взаємодії полягають у встановленні прийнятної для обох партнерів дистанції у спілкуванні, або міри емоційної близькості; виробленні способів вирішення конфліктів у разі незгоди подружжя один з одним. Визначення оптимальної дистанції у спілкуванні залежить від здатності кожного з партнерів знайти свої власні межі. Як видно з даних табл. 1, легкість спілкування була порушена в усіх парах ОГ та спостерігалась (хоча і не високого ступеня) у пар ГП (розбіжності між парами різних груп значущі на рівні $\mathrm{p}<0,05$ між чоловіками і $<<0,01$ між дружинами).

Шкала «психотерапевтичності» спілкування характеризує, наскільки спілкування сприяє створенню комфортної та інтимної атмосфери в сім’ї. Саме у психологічній підтримці, взаєморозумінні, дружньому, шанобливому ставленні один до одного криється так звана «психотерапевтична» функція спілкування в парі, яка була порушена в усіх подружжів ОГ, на відміну від такої у ГП (розбіжності значущі на рівні $\mathrm{p}<0,05)$.

Таким чином, незадоволення потреби подружжів ОГ у довірливості, емоційному прийнятті, взаєморозумінні, схожості в поглядах, у психологічній підтримці й захисті, позитивних емоціях через спілкування, ставало і причиною, і результатом незадоволення подружніми стосунками, на відміну від такого у пар ГП.

За розширеного вивчення особливостей міжособистісної взаємодії не тільки на рівні подружнього спілкування, а й як загального особистісного патерна, що було здійснено за допомогою методики діагностики міжособистісних стосунків Т. Лірі, встановлено таке (табл. 2).

«Владний - лідируючий» тип міжособистісних відносин (І октант) невиражено проявлявся у представників ОГ та був більше виражений у ГП, характеризувався оптимістичністю, швидкістю реакції, високою активністю, вираженою мотивацією досягнення, тенденцією до домінування, підвищеним рівнем домагань, легкістю і швидкістю у прийнятті рішень, гомономністю (тобто орієнтацією на власну думку й мінімальну залежність від зовнішніх факторів), екстравертованістю. Вчинки й висловлення почасту випереджали їхню продуманість. Їм властиво реагування, зумовлене щохвилинними потребами, виражена тенденція до спонтанної самореалізації, активний вплив на оточення, завойовницька позиція, прагнення вести за собою й підкоряти своїй волі інших. Таким чином, I октант виявляв характерний для стенічної, домінантної особистості тип міжособистісних відносин, що проявлявся на рівні соціальної активності у вигляді лідерських тенденцій.

ІІ октант відповідав «незалежному - домінуючому» типу міжособистісних відносин, спостерігався у частини жінок ОГ, сполучався з такими особливостями, як риси самовдоволення (самозакоханості), дистантність, егоцентричність, завищений рівень домагань, виражене почуття суперництва, що проявляється у

Таблиия 2. Середні показники шкал за методикою діагностики міжособистісних стосунків, бали

\begin{tabular}{l|c|c|c|c}
\hline \multirow{2}{*}{\multicolumn{1}{c|}{ Октанти }} & \multicolumn{2}{|c|}{ ОГ $(\mathrm{n}=73)$} & \multicolumn{2}{c}{ ГП $(\mathrm{n}=36)$} \\
\cline { 2 - 5 } & чоловіки & дружини & чоловіки & дружини \\
\hline Авторитарний & $10,2^{\#}$ & $9,5^{\#}$ & 5,4 & 4,7 \\
Егоїстичний & $9,6^{\#}$ & $8,8^{\#}$ & 4,6 & 5,2 \\
Агресивний & $8,1^{*}$ & $9,2^{*}$ & 4,1 & 3,8 \\
Підозрілий & $8,3^{*}$ & 6,1 & 3,9 & 4,4 \\
Підкорюваний & $5,3^{*}$ & $7,2^{*}$ & 3,8 & 5,6 \\
Залежний & $7,4^{\#}$ & 8,1 & 4,2 & 7,9 \\
Дружелюбний & $4,3^{\#}$ & $5,7^{*}$ & 7,3 & 7,1 \\
Альтруїстичний & $3,1^{*}$ & $5,1^{*}$ & 6,9 & \\
\hline
\end{tabular}


прагненні зайняти відособлену позицію у групі. Думка навколишніх сприймалася даними особами критично, власна думка зводилась у ранг догми або категорично відстоювалася. Емоціям бракувало тепла, учинкам - конформності.

«Прямолінійний - агресивний» тип міжособистісних відносин (перевага показників III октанта) був характерний для чоловіків ОГ. Йому властиві ригідність установок обстежених, що сполучалась із завзятістю в досягненні мети, підвищеним почуттям справедливості, переконаністю у власній правоті, виникненням почуття ворожості при протидії й критиці у свою адресу, безпосередністю і прямолінійністю у висловленнях і вчинках, підвищеною уразливістю, що легко згасала в комфортній ситуації.

«Недовірливий - скептичний» тип міжособистісних відносин (IV октант) частіш за все був виражений у чоловіків ОГ, проявлявся такими особистісними характеристиками, як відособленість, замкнутість, ригідність установок, критичне ставлення до будь-яких думок крім власної, підозрілість, надчутливість до критичних зауважень у свою адресу, неконформність суджень і вчинків, схильність до побудови ригідних і надцінних умовиводів, пов'язаних із переконаністю в недоброзичливості навколишніх осіб; випереджальна ворожість у висловленнях і поводженні.

V варіант - «покірний - соромливий» тип міжособистісних відносин - було виявлено в частки жінок ОГ - болісно соромливих, інтровертивних, пасивних, педантичних у питаннях моралі й совісті, невпевнених у собі, із підвищеною схильністю до рефлексії, помітною перевагою мотивації уникнення неуспіху й низькою мотивацією досягнення, заниженою самооцінкою, тривожними якостями із підвищеним почуттям відповідальності, незадоволених собою, схильних до того, щоб винити себе при невдачах.

VI октант - «залежний - слухняний» тип міжособистісних відносин - був характерний для чоловіків обох груп, причому в ОГ був виражений значніше, ніж у ГП. Вони виявляли високу тривожність, підвищену чутливість до впливів зовнішнього середовища, тенденцію до вираженої залежності власної думки від думки навколишніх. Потреба у прихильності й теплих відносинах була в них провідною. Непевність у собі була тісно пов'язана 3 не- стійкою самооцінкою. Ретельність і відповідальність створювала їм гарну репутацію в групі, однак інертність у прийнятті рішень, конформність установок і непевність у собі не сприяли їхньому просуванню на роль лідера. Підвищена чутливість до неуважності й брутальності навколишніх, надлишкова самокритичність, побоювання неуспіху як основа мотиваційної спрямованості формували канву конформного поводження.

VII октант - «спільнодіючий - конвенціальний» тип міжособистісних відносин, що більше був притаманний подружжям ГП, ніж парам ОГ, характеризувався такими індивідуальноособистісними характеристиками, як емоційна нестійкість, високий рівень тривожності й низький - агресивності, підвищена реакція на зовнішні впливи, залежність самооцінки від думки значущих інших, прагнення відповідати експектаціям групи, схильність до співробітництва. Відмічалась екзальтація, потреба у виливі дружелюбності на навколишніх, пошуки визнання в очах найбільш авторитетних особистостей групи. Виявлено прагнення знайти спільність із іншими, сприйнятливість до емоційного настрою групи.

VIII октант, перевага якого означала наявність «відповідального - великодушного» типу міжособистісної взаємодії, був діагностований переважно в подружжів ГП, сполучався з такими особистісними особливостями, як виражена потреба у відповідності соціальним нормам поведінки, схильність до ідеалізації гармонії міжособистісних відносин, екзальтація у прояві своїх переконань, виражена емоційність поверхневого змісту, необхідність створювати приємне враження, подобатися навколишнім.

Таким чином, ми спостерігаємо специфічні патерни міжособистісної поведінки чоловіків та жінок обох груп. Так, для чоловіків ОГ характерними були риси октантів підозрюваності, залежності та агресивності, для їхніх дружин - використання рис агресивності та підкорюваності. У подружжів ГП превалювали «владний - лідируючий», «спільнодіючий - конвенціальний» та «відповідальний - великодушний» октанти.

Наступним кроком дослідження було вивчення характерних стратегій психологічного захисту, результати чого наведено в табл. 3 . Психологічний захист є регулятивною систе- 
Таблиця 3. Розподіл домінуючих стратегій психологічного захисту у спілкуванні, \%

\begin{tabular}{l|c|c|c|c}
\hline \multirow{2}{*}{ Механізми захисту } & \multicolumn{2}{|c|}{ ОГ $(\mathrm{n}=73)$} & \multicolumn{2}{c}{ ГП $(\mathrm{n}=36)$} \\
\cline { 2 - 5 } & чоловіки & дружини & чоловіки & дружини \\
\hline Миролюбство & - & $12,3^{\star \wedge}$ & $77,8^{*}$ & 86,1 \\
Уникання & 67,1 & $58,9^{*}$ & $22,2^{*}$ & 13,9 \\
Агресія & $32,9^{*}$ & $28,8^{*}$ & - & - \\
\hline
\end{tabular}

мою стабілізації особистісних реакцій, що спрямована на усунення почуття тривоги, страху, пов'язаного з усвідомленням конфлікту, та врешті-решт зберігає сфери свідомості від негативних, травмуючих особу переживань $[10]$.

Уникання було чітко вираженою стратегією психологічного захисту, що виявилась притаманною $67,1 \%$ чоловіків і 58,9 \% жінок ОГ та 22,2 \% чоловіків і 13,9\% жінок ГП. Максимально вираженим встановлено уникання в чоловіків і жінок ОГ. Превалювання психологічного захисту за типом уникання виражалося в тому, що індивід без бою залишав зони конфліктів і напружених ситуацій у міжособистісному спілкуванні. При цьому обстежені уникали і відкритих проявів емоцій. Стратегія уникнення часто вимагала від особистості нервових витрат і супроводжувалась емоційними переживаннями, що спричиняло виникнення i/або поглиблювало внутрішньоособистісний конфлікт подружжів ОГ.

32,9 \% чоловіків і 28,8 \% жінок ОГ провідною стратегією спілкування використовували агресію. При цьому вони дозволяли собі бурхливі емоційні спалахи, були розгальмованими і не зважали на моральні норми поведінки, для них було характерним небажання пристосовуватись до оточуючих, мати з ними безконфліктні відносини.

Миролюбство було притаманним переважно подружжям ГП (77,8 \% чоловіків і 86,1 \% дружин). Це передбачало партнерство і співробітництво в міжособистісних відносинах, уміння знайти компроміс, готовність жертвувати своїми інтересами в ім'я збереження гідності. Однак миролюбство означало пристосування, тенденцію поступатися натиску партнера, не загострювати відносин і не вплутуватись у конфлікти, уникаючи їх.

Таким чином, вивчено закономірності міжособистісного і внутрішньосімейного спілкування в парах, де чоловіки страждають на ХП. Результати допомогли нам пояснити природу виникнення подружньої незадоволеності в парах, яка має переважно психогенну природу. Подружжя ГП виявились компенсованими завдяки відволіканню в інші сфери особистісного функціонування, використанню психологічного захисту миролюбства на тлі стратегій підкорюваності й дружелюбності партнерів, тоді як переважна більшість подружжів ОГ демонструвала або агресивний, або уникаючий модус поведінки партнерів.

\section{Висновок}

Загальними негармонійними міжособистісними патернами, які впливають на розвиток подружньої незадоволеності, що призводить до вторинної травматизації подружжів через формування неадекватної психологічної відповіді на захворювання на хронічний простатит у чоловіка та пов'язані з цим порушення сексуальної реалізації, визначено такі деформації родинного спілкування, як зниження довірливості, взаєморозуміння, легкості та психотерапевтичності; превалювання ознак недовірливо-скептичного, прямолінійно-агресивного, залежного патерна міжособистісної поведінки або такого, що підкорює; домінування агресії (32,9\%) або уникання $(67,1 \%)$ як провідних стратегій психологічного захисту у спілкуванні.

\section{Перспективність досліджень}

Отримані дані необхідно враховувати при розробці заходів медико-психологічної допомоги подружнім парам, у яких чоловік хворіє на хронічний простатит.

\section{Список літератури}

1. Chronic prostatitis / chronic pelvic pain syndrome increases susceptibility to seizures in rats and alters brain levels of IL-1 $\beta$ and IL-6 / N. Sutulovic, Z. Grubac, S. Suvakov [et al.] // Epilepsy Research. 2019. - Vol. 153. - P. 19-27. - DOI : https://doi.org/10.1016/j.eplepsyres.2019.03.014.

2. Assessing psychological factors, social aspects and psychiatric co-morbidity associated with chronic prostatitis / chronic pelvic pain syndrome (CP/CPPS) in men - a systematic review / B. Riegel, 
C. A. Bruenahl, S. Ahyai [et al.] // Journal of psychosomatic research. - 2014. - Vol. 77 (5). - P. $333-$ 350. - DOI : https://doi.org/10.1016/j.jpsychores.2014.09.012.

3. The role of psychosocial processes in the development and maintenance of chronic pain / R. R. Edwards, R. H. Dworkin, M. D. Sullivan [et al.] // The Journal of Pain: Official Journal of the American Pain Society. - 2016. - Vol. 17 (suppl. 9). - T70-T92. - DOI : https://doi.org/10.1016/j.jpain.2016.01.001.

4. Differential influence of early life and adult stress on urogenital sensitivity and function in male mice / I. M. Fuentes, A. N. Pierce, E. R. Di Silvestro [et al.] // Frontiers in systems neuroscience. 2018. - Vol. 11, issue 97. - DOI : https://doi.org/10.3389/fnsys.2017.00097.

5. Hohenfellner $U$. Psychische Komorbiditaten bei somatoformen Miktionsstorungen / U. Hohenfellner // Der Urologe. - 2016. - Vol. 55 (8). - P. 1109-1120. - DOI : https://doi.org/10.1007/s00120-016-0193-3.

6. Sexual and relationship functioning in men with chronic prostatitis/chronic pelvic pain syndrome and their partners / K. B. Smith, C. F. Pukall, D. A. Tripp, J. C. Nickel // Archives of sexual behavior. 2007. - Vol. 36 (2). - P. 301-311. - DOI : https://doi.org/10.1007/s10508-006-9086-7.

7. Predictors of sexual and relationship functioning in couples with chronic prostatitis / chronic pelvic pain syndrome / K. B. Smith, D. Tripp, C. Pukall, J. C. Nickel // J. Sex Med. - 2007. - Vol. 4 (3). P. 734-744. - DOI : 10.1111/j.1743-6109.2007.00466.x.

8. Потапенко $O$. A. Сексуальная дезадаптация супружеской пары при урологической патологии у мужа и её психотерапия / О. А. Потапенко // Медична психологія. - 2007. - Т. 2, № 1. - С. 66-68.

9. Домораикий В. А. Медицинская сексология и психотерапия сексуальных расстройств / В. А. Доморацкий. - М. : Академический Проект; Культура, 2009. - 470 с.

10. Райгородский Д. Я. Практическая психодиагностика. Методики и тесты : учебное пособие / Д. Я. Райгородский. - Самара : БАХРАХ, 1998. - 672 с.

\section{References}

1. Sutulovic N., Grubac Z., Suvakov S., Jovanovic D., Puskasc N., Macut D. et al. (2019). Chronic prostatitis / chronic pelvic pain syndrome increases susceptibility to seizures in rats and alters brain levels of IL-1 $\beta$ and IL-6. Epilepsy Research, vol. 153, pp. 19-27, DOI https://doi.org/10.1016/ j.eplepsyres.2019.03.014.

2. Riegel B., Bruenahl C.A., Ahyai S., Bingel U., Fisch M., Lowe B. (2014). Assessing psychological factors, social aspects and psychiatric co-morbidity associated with chronic prostatitis / chronic pelvic pain syndrome (CP/CPPS) in men - a systematic review. Journal of Psychosomatic Research, vol. 77 (5), pp. 333-350, DOI https://doi.org/10.1016/j.jpsychores.2014.09.012.

3. Edwards R.R., Dworkin R.H., Sullivan M.D., Turk D.C., Wasan A.D. (2016). The role of psychosocial processes in the development and maintenance of chronic pain. The Journal of Pain: Official Journal of the American Pain Society, vol. 17 (suppl. 9), T70-T92, DOI https://doi.org/10.1016/ j.jpain.2016.01.001.

4. Fuentes I.M., Pierce A.N., Di Silvestro E.R., Maloney M.O., Christianson J.A. (2018). Differential influence of early life and adult stress on urogenital sensitivity and function in male mice. Frontiers in Systems Neuroscience, vol. 11, issue 97, DOI https://doi.org/10.3389/fnsys.2017.00097.

5. Hohenfellner U. (2016). Psychische Komorbiditaten bei somatoformen Miktionsstorungen [Psychological comorbidities in patients with psychosomatic disorders of micturition]. Der Urologe, vol. 55 (8), pp. 1109-1120, DOI https://doi.org/10.1007/s00120-016-0193-3 [in German].

6. Smith K.B., Pukall C.F., Tripp D.A., Nickel J.C. (2007). Sexual and relationship functioning in men with chronic prostatitis / chronic pelvic pain syndrome and their partners. Archives of Sexual Behavior, vol. 36 (2), pp. 301-311, DOI https://doi.org/10.1007/s10508-006-9086-7.

7. Smith K.B., Tripp D., Pukall C., Nickel J.C. (2007). Predictors of sexual and relationship functioning in couples with chronic prostatitis / chronic pelvic pain syndrome. J. Sex Med., vol. 4 (3), pp. 734-744, DOI 10.1111/j.1743-6109.2007.00466.x.

8. Potapenko O.A. (2007). Seksualnaia dezadaptatsiia supruzheskoi pary pri urolohicheskoi patolohii u muzha i yeio psikhoterapiia [Sexual maladjustment of a married couple with urological pathology in a husband and her psychotherapy]. Medychna psykholohiia - Medical Psychology, vol. 2, № 1, pp. 66-68 [in Russian]. 
9. Domoratskii V.A. (2009). Meditsinskaia seksolohiia i psikhoterapiia seksualnykh rasstroistv [Medical sexology and psychotherapy for sexual disorders]. Moscow: Akademicheskii Proiekt; Kultura, 470 p. [in Russian].

10. Raihorodskii D.Ya. (1998). Prakticheskaia psikhodiahnostika. Metodiki i testy: uchebnoie posobiie [Practical psychodiagnostics. Techniques and tests: textbook guide]. Samara: Bakhrakh, 672 p. [in Russian].

\section{В.А. Кривицкий}

\section{АНАЛИЗ ОСОБЕННОСТЕЙ МЕЖЛИЧНОСТНОГО ВЗАИМОДЕЙСТВИЯ У БОЛЬНЫХ ХРОНИЧЕСКИМ} ПРОСТАТИТОМ С РАЗНЫМ СОСТОЯНИЕМ СУПРУЖЕСКОЙ УДОВЛЕТВОРЕННОСТИ

Изучены особенности межличностного взаимодействия у больных хроническим простатитом и их жен для определения мишеней медико-психологической помощи данному контингенту. Обследованы 109 мужчин, больных хроническим простатитом, и их жены. По критерию наличия / отсутствия супружеской удовлетворенности обследованные пары были разделены на две группы. В первую группу вошли 73 (67,0 \%) пары с низким или пониженным уровнем супружеской удовлетворенности, во вторую - 36 (33,0 \%) супружеских пар, довольных собственными отношениями. Комплексное обследование проведено стандартными клиническими, клинико-психологическим и психодиагностическим методами. Общими негармоничными межличностными паттернами, которые влияют на развитие супружеской неудовлетворенности, что приводит к вторичной травматизации супругов путем формирования неадекватного психологического ответа на заболевание хроническим простатитом у мужа и связанные с этим нарушения сексуальной реализации, определены такие деформации семейного общения, как снижение доверчивости, взаимопонимания, легкости и психотерапевтичности; превалирование признаков недоверчиво-скептического, прямолинейно-агрессивного, зависимого или подчиняющего паттернов межличностного поведения; доминирование агрессии $(32,9 \%)$ или ухода $(67,1 \%)$ в качестве ведущих стратегий психологической защиты в общении. Полученные данные необходимо учитывать при разработке мероприятий медико-психологической помощи супружеским парам, в которых мужчина страдает хроническим простатитом.

Ключевые слова: хронический простатит, супружеская удовлетворенность, межличностное общение.

\section{V.A. Kryvytskyi \\ ANALYSIS OF INTERPERSONAL INTERACTION FEATURES IN PATIENTS WITH CHRONIC PROSTATITIS WITH DIFFERENT STATUS OF MARRIAGE SATISFACTION}

The features of interpersonal interaction in patients with chronic prostatitis and their wives, to determine, in the future, the targets of medical and psychological care for this contingent were studied. 109 men with chronic prostatitis and their wives were examined. According to the criterion of presence / absence of marital satisfaction, the surveyed couples were divided into two groups. The first group included $73(67.0 \%)$ couples with low or reduced levels of marital satisfaction. The second included 36 (33.0\%) married couples who were satisfied with their own relationship. The comprehensive examination included, in addition to standard clinical methods, a clinical-psychological and psychodiagnostic study. By common disharmonious interpersonal patterns, which contributed to the development of marital dissatisfaction, which led to secondary trauma to spouses due to the formation of inadequate psychological response to chronic prostatitis in men and related sexual dysfunction, identified such deformations of family communication as reduction of trust, mutual understanding, ease and psychotherapy; prevalence of signs of distrustful-skeptical, straightforward-aggressive, dependent or submissive patterns of interpersonal behavior; dominance of aggression $(32.9 \%$ ) or avoidance $(67.1 \%)$ as the leading strategies of psychological protection in communication. The obtained data should be taken into account when developing measures of medical and psychological assistance to married couples in which the husband has chronic prostatitis.

Keywords: chronic prostatitis, marital satisfaction, interpersonal communication.

Надійшла 13.09.19

\section{Відомості про автора}

Кривицький Віталій Олександрович - здобувач кафедри сексології, медичної психології, медичної і психологічної реабілітації Харківської медичної академії післядипломної освіти; уролог-сексопатолог ТОВ «Медичний центр Здоров’я» (м. Харків).

Адреса: 61176, м. Харків, вул. Амосова, 5.

Тел.: +38(050)906-86-53.

E-mail: kryvychki2017@gmail.com.

ORCID: https://orcid.org/0000-0002-0521-4660. 